\title{
CONCEPT REDUNDANCY AND CONTAMINATION IN EMPLOYEE COMMITMENT RESEARCH: CURRENT PROBLEMS AND FUTURE DIRECTIONS
}

\author{
GERT ROODT \\ Department of Human Resource Management \\ Rand Afrikaans University \\ gr@ujhb.ac.za
}

\begin{abstract}
It is generally accepted that employee commitment has a significant impact on organisational performance. The primary goal of this article is to indicate that the 'commitment/involvement' concept did not evolve in an evolutionary and progressive fashion. Several problems in the development course of mainly three streams of research literature are indicated. Arguments are presented for indicating causes of concept contamination and even redundancy. In order to bridge these problems, a motivational approach as an integrating mechanism on a metatheoretical level is presented as a solution. The outcomes thereof should lead to better order on a theoretical level and to the parsimonious use of commitment concepts.
\end{abstract}

\section{OPSOMMING}

Dit word algemeen aanvaar dat werknemertoewyding 'n duidelike impak op organisasieprestasie het. Die primêre doel van hierdie artikel is om aan te dui dat die ontwikkeling van die 'betrokkenheid/toewydings-' konsep nie evolusionêr en progressief verloop het nie. Verskeie probleme in die ontwikkelingsgang van hoofsaaklik drie strome navorsingsliteratuur word aangedui. Argumente word aangevoer wat op oorsake van konsepkontaminasie en selfs -oorbodigheid dui. Ten einde hierdie probleme te oorkom, word 'n motiveringsbenadering as integrerende meganisme op 'n meta-teoretiese vlak as oplossing voorgehou. Die uitkoms daarvan behoort tot beter orde op teoretiese vlak en tot die spaarsamige gebruik van toewydingskonsepte te lei.

High employee commitment (a continuum of alienation commitment), (hereafter only referred to as commitment) is a prominent feature of world-class companies. These companies have succeeded in designing and implementing high performance and high involvement practices, resulting in their success. Recent research (Harter, 2000a, 2000b; Fleming, 2000a, $2000 \mathrm{~b})$ has indicated that employee commitment is an important variable to predict organisational performance and even the performance of national economies. In the view of the importance of such a concept, it needs to be carefully analysed and precisely defined.

\section{Problem statement}

A number of researchers (Knoop, 1986; Morrow, 1983; Morrow \& McElroy, 1986; O'Reilly \& Chatman, 1986; Rabinowitz \& Hall, 1977) have pointed out the fact that research in the wider arena of employee commitment did not evolve in a logical, coherent and progressive fashion. This research could rather be described as haphazard, fragmented and evolving along different avenues. Employee commitment evolved as a wide range of 'types' (e.g. engagement, attachment, commitment, involvement) within a wide spectrum of foci (e.g. work, job, career, profession/ occupation, organisation, union), while categories towards studying commitment varied between behavioural, attitudinal and motivational within three broad research streams (sociological, industrial/organisational psychology and health psychology). The domains of the current state of research in employee commitment can be best depicted as in Figure 1.

It is therefore argued that most researchers took little cognisance of contradictory research findings and/or of different theorisations about various concepts of employee commitment. As a result, research in the commitment field is characterised by concept redundancy and concept contamination. Concept redundancy in this context refers to the use of related variables that largely overlap in meaning, e.g. work involvement and work commitment. Concept contamination occurs when a variable contains a large

Requests for copies should be addressed to: G Roodt, Department of Human Resource Management, RAU University, PO Box 524, Auckland Park, 2006 proportion of shared or common content with other 'unrelated' variables, e.g. morale and work involvement. This results in poor theory building and development with regard to employee commitment.

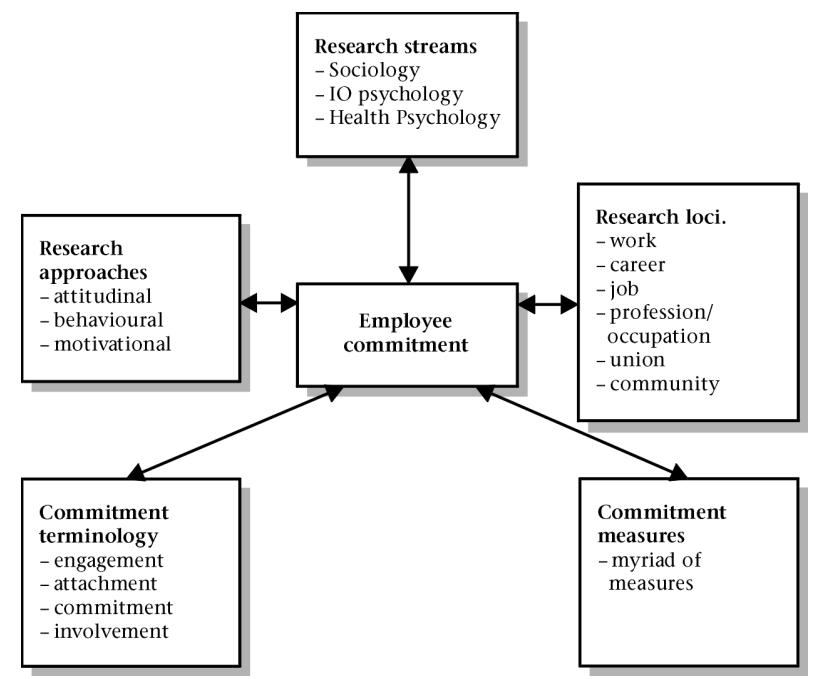

Figure 1: Important domains of commitment research

The purpose of this article is therefore to firstly, introduce the current state of commitment research in five employee commitment domains (refer to Figure 1) and secondly, to indicate the consequences of the current state of affairs. Thirdly, a solution for the current state of affairs will be proposed.

The current state of commitment research in five domains The current state of commitment research can be best described in terms of the developments in five domains as explained in Figure 1 . The following four sub-sections will introduce: 1 ) the three broad research streams and resulting terminology; 2) the three categories of approaches to commitment research; 3) a range of different commitment foci; and 4) a myriad of commitment measures. 
Three separate, broad research streams of commitment resulting in a profusion of commitment terms

These separate research streams will be introduced in the section below. Owing to limited space, only the essence of the research trends is presented here, and not a full review of the literature in all three research streams.

Three broad parallel research streams have evolved around commitment; namely the sociological, the industrial/ organisational (I/O) psychology (including management literature) streams as identified and integrated by Kanungo $(1979,1981,1982 a)$ and the health-psychology stream that is added as a third stream (Roodt, 1991, 1994a). The sociological stream focuses on alienating, antecedent social conditions that are 'objectively' assessed by a subject expert. The I/O psychology stream focuses on the state of commitment, subjectively experienced by an individual and is characterised by a focus on antecedent and consequential behaviours and conditions. The health-psychology stream deals with particular predispositions and the negative consequences of extreme or excessive commitment. An overview of research within these three streams will be discussed in more detail in a following section.

Within each of the mentioned research streams a proliferation of concepts evolved, with very little attempts at parsimony or attempts at eliminating concept redundancy or concept contamination. Some authors need to be mentioned for attempting to create order and clarity on a theoretical level. Morrow (1983) stressed the lack of an evolutionary development of the construct, while Brown, R.B. (1996); Brown, S.P. (1996); Forrest, Cummings and Johnson (1977); Kanungo (1982a); Reichers (1985) internationally, and Roodt (1991), and Roodt, Bester and Boshoff, (1994a) locally, made concerted efforts in integrating and developing a motivational approach to involvement.

Different theoretical approaches were followed within each of the research streams and these can be categorised in three broad groups.

Categories of approaches towards studying commitment

A different framework for categorising the theoretical development of commitment, is the distinction between two seemingly divergent schools of thought (Scholl, 1981), namely the behavioural and the attitudinal schools (cf. Brown, R.B., 1996; Hoole, 1997). A third and integrative school of thought is the motivational school (Kanungo, 1982a; Lefkowitz, Somers \& Weinberg, 1984; Roodt, 1991) that emerged at a later stage. The theoretical approaches of these schools are different and are explained briefly below.

The behavioural approach to commitment (Becker, 1960; Lodahl $\&$ Kejner, 1965) identified a number of commitment behaviours in the work context. Terms such as, 'investments' and 'side-bets', were used to describe some commitment behaviours. This approach unfortunately did not distinguish between the antecedents, the state of commitment itself and its consequences. The behavioural approach is particularly problematic, because behaviour is multi-deterministic; i.e. predictors related to a particular behaviour can also predict other behaviours. Antecedent and consequential behaviours of commitment can also be related to other determinant or consequential conditions such as job satisfaction, morale or intention to leave. The state of commitment should therefore be precisely defined, as was also pointed out by Day (1994) and Scholl (1981).

The attitudinal approaches (Allen \& Meyer, 1996; Mowday, Steers \& Porter, 1979), probably originated from Etzioni's (1964) work, normally refer to three components of commitment, namely normative commitment, affective commitment and continuance commitment (cf. Meyer, Allen \& Smith, 1993). Normative commitment refers to a sense of obligation to the relevant focus, e.g. work, while affective commitment refers to the identification with, involvement in and emotional attachment to the focus in question. Continuance commitment refers to involvement based on the cost associated with abandoning the particular focus. These three components correspond with some attitude theories that contain a cognitive (normative), an affective (emotional), and a conative (continuance) element (also refer to Figure 1). The attitudinal approach to commitment, currently dominating the research literature, has some limitations. Firstly, the commitment construct is conceptualised as being multi-dimensional which poses problems in predictive models and from a conceptual perspective does not meet the criteria for parsimony, clarity and precision; and secondly, it includes an affective as well as a conative component which creates a conceptual overlap with job attitudes such as job satisfaction and job intentions such as intention to leave respectively or moral and/or normative commitment such as work values.

The motivational approach is a third school of thought that emerged recently in an attempt to integrate the diverse perspectives and also to overcome the most important limitations of the other two approaches. The motivational approach was proposed by Kanungo (1982a) and variations thereof were used amongst others by Harter (2000a); Lefkowitz, Somers and Weinberg (1984); and Misra, Kanungo, Rosenstiel and Stuhler (1985); and Roodt (1991, 1993, 1994a, 1994b, 1997). This approach only focuses on the state of commitment in a particular focus. The state of commitment is not only separated from its antecedent and consequential conditions and behaviours, but also from its related affective and conative components that are also present in other widely used constructs, such as job satisfaction and intention to leave respectively.

Poor theoretical integration and poor theory building, unfortunately still permeates each research stream and approach to commitment. Few attempts have been made to eliminate construct redundancy and construct contamination across different research streams and approaches. This has contributed largely to the development of a wide range of different commitment foci.

\section{A range of different commitment foci}

A review of the literature reveals a number of different workrelated foci of commitment, namely work, job, career, profession/occupation, organisation, union, community, supervisor, manager, and work-unit or division. Non-work foci in other spheres of life could also be added to this list, but fall outside the ambit of work-related commitment and would therefore not be discussed further.

One may wonder what the purpose is of distinguishing between all these different work-related foci. The answer would probably be to better understand the dynamics of employee commitment in the work context. This would also include the issue of relative importance of the different foci to employees. But a valid concern raised by Morrow, Eastman and McElroy (1991) was whether raters, who are not subject experts, can validly distinguish between different commitment foci. In this regard Roodt (1997) found that when six foci (work, job, career, profession, organisation and union), were operationalised on the same theoretical basis, (as a cognitive predisposition), only the focus 'union' emerged as a separate focus after scores were factor analysed. Mathieu and Farr (1991) supported the findings of Brooke, Russell and Price (1988) who found evidence of discriminant validity between organisational commitment, job involvement and job satisfaction. Allen and Ortlepp (2002) also argued a case for distinguishing between work and career salience. It seems that researchers, who have reported 'construct' and discriminant validity for the instruments they have used, capitalised on the effect of using different theoretical foundations and measures. It can therefore be argued that a more parsimonious approach in the use of work-related commitment foci is needed. 
A myriad of measures

Based on the different theoretical approaches and the wide range of commitment foci a myriad of measures were developed to assess commitment behaviours. Morrow (1983) identified not less than 32 different commitment measures with five different foci, namely values, career, job, organisation and union. This list is not nearly comprehensive or complete, since several measures were developed after this date. Cook, Hepworth, Wall and Warr (1979) listed several measures that have been designed to measure either commitment or alienation in the work context.

Only a few measures were specifically designed to assess commitment as a cognitive predisposition (a motivational approach) toward a particular focus, namely the instruments used by Harter (2000a, 2000b), Kanungo (1982a), and Roodt (1993, 1997).

It does not fall within the ambit of this article to provide a comprehensive list of all commitment measures. A review of the literature however, has shown that many additional measures were developed since Morrow's (1983) call for a moratorium on the further development of commitment measures, without paying much attention to any of the pitfalls mentioned by Morrow.

The section above shed some light on the current state of commitment research and the following section of this article will deal with the consequences of this state of affairs.

\section{Consequences of the current state of commitment research}

This section on the consequences of the current state of commitment research will introduce three important issues, namely: 1) concept redundancy and contamination; 2) sources of concept redundancy and contamination; and 3) poor theoretical foundation and integration. This section will conclude by indicating why concept redundancy and contamination is an important issue in commitment research and why integration on a meta-analytical level needs to take place.

\section{Concept redundancy and contamination}

Within the three mentioned, broad research streams, several concepts were coined and used. Several attempts have been made to illustrate the empirical relationship between the variables within each stream, but few researchers attempted to address this problem on a meta-theoretical level.

In the sociological literature, which focused mainly on the alienation side of the commitment continuum, concepts such as the following were used to describe the sociological state of alienation or alienation-related conditions (also compare Dean, 1961): apathy (Keniston, 1957), anomie (in the early writings of Durkheim, 1893; Hegel, 1949; Marx, 1963), authoritarianism (Adorno, 1950), automation, bureaucratisation (Bonjean \& Grimes, 1970), conformity (Fromm, 1958), cynicism (Merton, 1947), hoboism (Grodzins, 1956), prejudice (Adorno, 1950), psychosis (Jaco, 1954) privatisation (Kris \& Leites, 1950), regression (DeGrazia, 1948), political apathy (Rosenberg, 1951), political hyperactivity (Riesman \& Glazer, 1950) personalisation in politics (Adorno, 1950) or even suicide (Powell, 1958), which are in most cases related to social-structural conditions. Sociological alienation was thus assessed on a group or a social systems level by using epi-phenomenological categories such as 'powerlessness' and 'normlessness' (Seeman, 1959) to describe socio-pathological conditions.

Several attempts have been made in this research stream to determine the discriminant validity or convergent validity of some of these mentioned constructs. Struening and Richardson (1965); Simmons (1966) and Neal and Rettig (1967) supported a dimensional approach to alienation based on factor analytical evidence. McDill (1961) tried to clarify the relationship between anomie, authoritarianism and socio-economic status and provided evidence for a single factor solution. Seybolt and Gruenfeld (1976) argued a case for concept redundancy between job satisfaction and work alienation and this was supported at a later stage by Lefkowitz and Brigando (1980). Knapp (1976) conducted a factor analytic study on 14 measures of authoritarianism, alienation, status concern and the tendency to discriminate and pointed out problems with the use of multidimensional instruments.

In the $\underline{I} / \mathrm{O}$ psychology literature (including management literature), which focused mainly on the involvement side of the continuum, concepts like the following were used to describe the psychological state of commitment: Central life interest (Dubin, 1956), Protestant work ethic (Blood, 1969), work involvement (Allport, 1943, 1947; Dubin, 1956; French \& Kahn, 1962; Patchen, 1970; Vroom, 1964) ego-involvement (Vroom, 1962; Wickert, 1951), morale (Guion, 1958; Stagner, 1958), attachment (O'Reilly \& Chatman, 1986), engagement (Harter, 2000a, 2000b) organisational identification (Hall, Schneider \& Nygren, 1970), organisational involvement (Brown, M.E., 1969), intrinsic motivation and job satisfaction. Psychological commitment was thus mostly assessed on an individual level by focussing on subjective work experiences.

Similar attempts have been made in the I/O research stream to clarify these mentioned concepts. Shore, Thornton and Shore (1990) provided evidence for discriminant validity of job involvement, organisational commitment and career salience. Wiener and Gechman (1977) again, argued a case for no distinction between job commitment and job involvement. Lawler and Hall (1970) and Cummings and Bigelow (1976) found evidence for distinguishing between job involvement, job satisfaction and intrinsic motivation. Saal (1978) found significant relationships between job involvement, Protestant work ethic, job satisfaction and achievement motivation. Saal (1981) compared a multi-dimensional and a uni-dimensional measure of job involvement and reported no differences in respect of a range of correlates. Blau (1985) provided evidence for concept redundancy between some measures of job involvement and intrinsic motivation, but has indicated support for job involvement as a uni-dimensional construct. Mortimer and Lorence (1989) argued the case for a distinction between satisfaction and involvement. Allen and Ortlepp (2002) provided evidence for distinguishing between work and career salience. In the research cited above work commitment was operationalised in distinct ways: firstly, on different theoretical grounds; secondly, as uni-dimensional constructs or thirdly as multi-dimensional constructs. These differences in theorisation may have contributed to the contradictory results.

Rabinowitz and Hall (1977) and Randall (1987) referred to the possible effects of extreme commitment and its negative consequences. From the health-psychology literature terms such as obsessive-compulsive orientation (Pollak, 1979), type A behaviour (Chonko, 1983; Schwartz, 1982), perfectionism (Pietropinto, 1986), management neurosis (Stewart, 1986), anal character (Naughton, 1987), and work addict (Pace, Suojanen, Bessinger, Lee, Frederick \& Miller, 1986; Pace \& Soujanen, 1988) have been used to describe persons who are excessively involved in their work.

Attempts have also been made in this research stream for greater concept clarity. Research by Chonko (1983); Naughton (1987) and Schwartz (1982) tried to clarify the relationships between obsessive-compulsive behaviour patterns and excessive work commitment. Price (1980) and Burke and Deszca (1982) again suggested a relationship between type A behaviour and workaholism. Roodt (1991) illustrated a conceptual overlap between obsessive-compulsive behaviour and the type A behaviour pattern, and their relationship with excessive work involvement. Roodt (1991, 1994a), extended the continuum of commitment (alienation - involvement as was suggested by Kanungo, 1982a; Lefkowitz et al., 1984) towards the more extreme end of commitment, based on empirical evidence. 
In research (Allen \& Ortlepp, 2002; Morrow \& McElroy, 1986) where different commitment foci operationalised on different bases were used, results most frequently indicate that the different foci are correlated and thus share some common variance. It also appears in some instances (Lawler \& Hall, 1970; Lefkowitz, Somers and Weinberg, 1984; Weissenberg \& Gruenfeld, 1968) that some commitment foci were highly correlated with other non-commitment work variables such as 'job satisfaction', 'intrinsic motivation', or 'need-satisfaction', which provides also additional support for the motivational approach. These results indicate that some of the concepts may be redundant and/or are contaminated by other variables.

About 20 years ago Morrow (1983, p. 489) aptly stated that: "the theoretical and empirical linkages among the five forms of work commitment are not readily apparent, nor have they been the focus of much comparative study." Since then, little comparative research on the different work-related foci was conducted, while little or no attempts were made to integrate the three mentioned streams and categories of approaches where different theoretical foundations were used. These issues may be important sources of concept redundancy and/or contamination and have still not been sufficiently addressed by researchers.

\section{Sources of concept redundancy and concept contamination}

Against the background of the above discussion Rokeach and Bartley (1978, p. 158) aptly remarked that: "One of the most disconcerting features of contemporary psychology is the unnecessary multiplication of concepts." Despite the fact that this comment was made about 25 years ago, researchers still proceed without paying much attention to this warning. The section below deals with possible sources of concept redundancy and/or of concept contamination.

\section{Lack of a comparative theoretical basis between commitment foci}

Most of the findings reported in the literature show different theorisations underpinning different measures. Cases in point are the definitions of organisational commitment by Allen and Meyer (1990), Cook and Wall (1980), Mowday et al. (1979), and Porter, Steers, Mowday and Boulian (1974). When job involvement is more closely examined, one finds different definitions by Allport (1943) Lodahl and Kejner (1965), Pinder (1984) and Reitz and Jewell (1979). The same argument is applied in the case of work involvement when the definitions by Jans (1982), Kanungo (1982a), and Newton and Keenan (1983) are revisited. Also, in the case of career commitment, different definitions were developed by Amatea, Cross, Clark \& Bobby (1986), Blau (1988) and Greenhaus (1971). Along similar lines Bagraim (2003) and Morrow and Goetz (1988) have used different measures to operationalise professional/ occupational commitment. Similar evidence exists in another work-related focus, i.e. union involvement where Fullagar and Barling (1989), Gordon, Philpot, Burt, Thomson and Spiller (1980) as well as Roodt $(1993,1997)$ developed various measures.
If such measures of job involvement and work or organisational commitment were to be tested for convergent validity, artificial differences would occur based on the different foundations used for operationalising the constructs (this can also be referred to as hetero-method variance). This is a clear case of comparing apples with oranges. Comparative studies on different commitment foci should rather be conducted on a comparable or a similar theoretical basis in order to compare apples with apples (this would again contribute to common method variance). In this regard, Roodt (1997) found that five foci of commitment (work, job, occupation, career and organisation) were significantly correlated and that only 'union' emerged as a separate focus when operationalised on the same theoretical basis, i.e. a cognitive predisposition to the focus. Significant statistical differences were still detected between the different foci, which indicate that common method variance was not too much of a confounding factor.

Kanungo's $(1979,1981,1982 a, 1982 b)$ attempts to clarify and propose a common theoretical basis for alienation (the sociological research stream) and involvement (the I/O research stream) equally apply to comparisons between other foci. Roodt (1991, 1994a) extended this commitment continuum by including the extreme commitment (based on the health psychology literature). It seems as if the golden thread running through all the definitions of commitment is the potential of a particular focus to satisfy salient needs. A motivational approach, which also includes the realisation of salient values and the achievement of salient goals, as suggested by Roodt (1991) seems to be more appropriate. Based on this potential for satisfying salient needs (Kanungo, 1982a), for realising salient values (Roodt, Bester \& Boshoff, 1994b; Ruh, White \& Wood, 1975) and for achieving salient goals (Roodt et al., 1994b), commitment is defined as a cognitive predisposition towards a particular focus, insofar this focus has the potential to satisfy needs, realise values and achieve goals. Needs, values and goals are all motivational constructs. This definition would provide the much-needed common basis for comparisons between different commitment foci.

\section{Unclear distinction between psychological activities}

The psychological activities of human beings are often divided into four categories, namely cognition (beliefs), affect (attitudes/emotions), conation (intentions) and manifest behaviour (see Fishbein, 1967; Fishbein \& Ajzen, 1975). The argument proposed here are that these psychological activities are distinguishable, but related components. Affect has a cognitive origin and is related to a range of possible behavioural intentions. There is a direct link between the three components and manifest behaviour as depicted in Figure 2 .

This theoretical model provides a basis for distinguishing between related concepts such as work commitment and work satisfaction. Based on this widely accepted distinction, commitment is defined as a cognitive predisposition (a belief state), based on the subjective assessment of the potential to satisfy salient needs (Brown, R.B., 1996). Job satisfaction on the

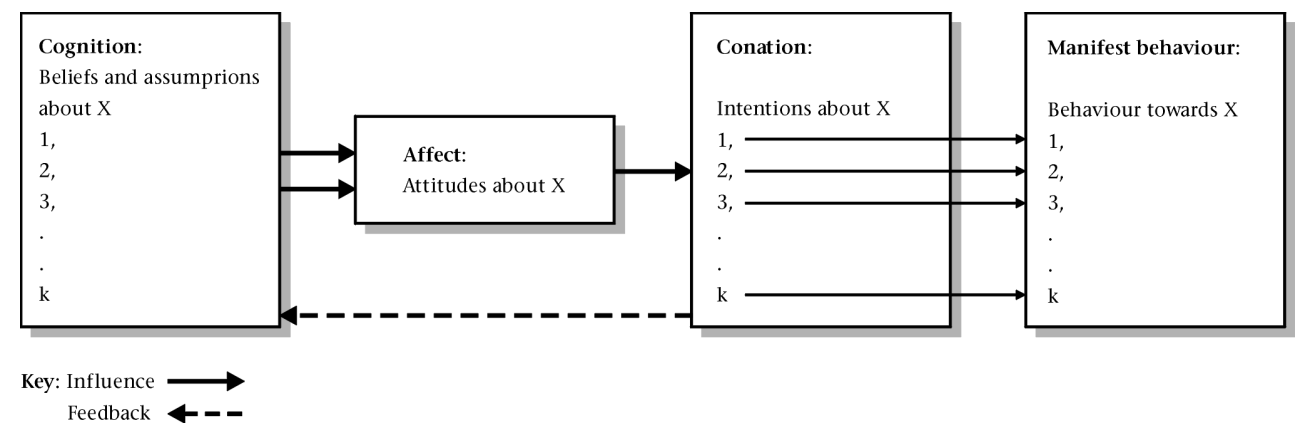

Figure 2: The link between cognition, affect, conation and manifest behaviour (adapted from Fishbein \& Ajzen, 1975) 
other hand is defined as a combination of emotions (affect) towards job-related objects or facets (Coster, 1992). Intention to leave can again be defined as conation, based on the content of cognition and affect.

In the case of measures of alienation, researchers found it difficult to separate the cognitive predisposition of alienation from its negative affect. Again, in the case of measures of commitment researchers failed to separate the cognitive predisposition of involvement from its positive affect. In most cases this resulted in construct contamination where this distinction between the different psychological activities was not drawn clearly. Many studies (Cheloha \& Farr, 1980; Gechman \& Wiener, 1975; Hollon \& Chesser, 1976; Mathieu \& Farr, 1991; Mester, Visser, Roodt \& Kellerman, 2003; Weissenberg \& Gruenfeld, 1968) reported significant correlations between measures of commitment and other measures of job satisfaction or intentions to leave and in doing so, may have capitalised on this conceptual contamination.

\section{Divergent psychological and sociological perspectives and}

\section{methodologies}

As mentioned before, Kanungo $(1979,1981,1982 a)$ identified the psychological approach to commitment and the sociological approach to alienation. Both approaches had their own methodological basis, which further contributed, to the artificial divide between involvement and alienation. Kanungo (1982a) pointed to the fact that commitment is normally assessed by means of self-report inventories. Subjects are thus reporting their own subjective experiences and perceptions. In the case of alienation, subject experts 'objectively' assess social-structural conditions or socio-pathologies.

\section{Distinguishing the state of commitment from its antecedents as and its consequences}

As was alluded to in the above sections, a further limitation in the operationalisation of commitment is that no clear distinction was drawn between the state of commitment, its antecedent conditions and behaviours (causes) and its consequential conditions and behaviours (effects) (Kanungo, 1982a).

Many measures (Lodahl \& Kejner, 1965; Saleh \& Hosek, 1976) contain items that refer to antecedent conditions or behaviours of commitment. This may result in construct contamination with other measures that tap into the same manifest behaviours such as job satisfaction, job dissatisfaction or even positive and negative affectivity.

Also, many measures (Lodahl \& Kejner, 1965; Patchen, 1965) contain items that refer to consequential conditions or behaviours of commitment. This may result in construct contamination with other measures that tap into the same manifest behaviours such as job satisfaction, negative affectivity, organisational citizenship, tardiness, absenteeism and intention to leave. This is a serious issue that needs urgent attention.

\section{Poor theoretical foundation and integration: pragmatic vs} theoretical considerations

In recent years a myriad of measures were developed to assess or measure a wide range of commitment-related concepts. These concepts and measures were seemingly most frequently based or formulated on pragmatic grounds. How the construct could be defined in a workable way seemed to be the most important consideration for authors: "What in our view is ... commitment?" After deciding on a definition the challenge was to operationalise the concept: "How can we measure this concept in a time and cost effective way?" This approach very often resulted in loosely defined concepts that were not theoretically well founded or integrated.

A number of measures do not distinguish between the antecedent conditions and behaviours, the state of commitment itself and the consequential conditions and behaviours. Antecedent and consequential conditions and behaviours may also be related to other constructs such as job satisfaction and job intentions.
It appears that very few attempts have been made to revisit existing concepts and to investigate their theoretical foundation. Only a limited number of articles were published that critically examined the theoretical foundations of the constructs or measures. Obviously, there are exceptions to the rule as in the case of Brown, R.B. (1996); Brown, S.P. (1996); Forrest et al. (1977); Kanungo (1982a); Morrow (1983), and Reichers (1985) to name but a few. It seems that the less tedious way was to invent a new measure rather than to search for, to critically review and to integrate the existing literature.

This resulted in most instances in a fragmented (poorly integrated), illogical and non-evolutionary development of most of the current commitment concepts and measures that can be grouped in three broad streams.

Why concept redundancy and contamination is a serious issue Struening and Richardson $(1965$, p. 776) have already pointed out about 40 years ago that:

the level of development of measurement models in the social sciences is a symptom of the status of the discipline as an empirical science, and the measurement studies done in this area in the last 14 years suggest, unfortunately, that we have neglected our professional responsibility to measure concepts accurately and comprehensively. (own emphasis)

It seems that this statement is still largely applicable today on the commitment literature.

Kerlinger (1986) clearly distinguished between concepts, constructs and variables and how they are related. Concepts are terms or labels attached to phenomena, while constructs are carefully defined and contain a specific meaning which distinguishes it from any other construct or concept. In this process care is taken to avoid overlap in meaning (contamination) with other concepts or to avoid duplicating other related concepts. In the process of theory building there should be clarity and precision in meaning, parsimony and internal logic (also refer to Rokeach \& Bartley, 1978). If these ground rules are not applied consistently, it will lead to construct contamination and even construct redundancy.

The issue of concept redundancy is also a concern when conducting comparative research between different research streams. Are the same constructs assessed when a person who measures low in work alienation obtains a high score in work commitment? Would such a person be classified as a workaholic? The use of a broad comprehensive theoretical model would enable researchers to address this issue.

As was illustrated above, concept contamination is a concern when conducting research where variables that should be treated as distinct, contain common or shared theoretical bases with other variables. A case in point is job satisfaction and job involvement where both variables tap into the same item basis of affective content, or antecedent and consequential conditions and behaviours. These contaminations would artificially enhance correlations between variables.

Saal (1981) tried to illustrate the empirical and theoretical implications of using a purely cognitive definition of job involvement and concluded that this restrictive (precise?) definition (of Kanungo, 1982a) might be applied without creating havoc in the existing job involvement literature. If his findings are interpreted correctly, he suggested that a cognitive approach would lead to more precise findings.

\section{A clear need for a meta-theoretical integration}

From the prior discussion it is clear that a dire need exists to create order on a theoretical level in the commitment literature. The current position with the wide range of different work-related commitment foci, (work, job, occupation/professional, career, organisation and union) and 
the wide spectrum of different forms of commitment (involvement, alienation, identification, attachment, engagement) creates an intolerable position. The different categories of commitment approaches (behavioural and attitudinal) within each of the research streams further add complexity to this position, if all the different combinations of assessing commitment are considered.

Also the state of commitment not only needs to be differentiated clearly from its antecedent and consequential conditions or behaviours, but also in terms of its psychological state, i.e. whether it is cognition, affect, conation, or all three. In the latter case it would alleviate problems to differentiate the state of commitment from job satisfaction (affect) or intentions to leave (conation). The only logical way it seems, would be to attempt a theoretical integration on a meta-theoretical level.

The third section of this article focuses on the proposed solution, namely integration on a meta-theoretical level.

The solution: Integration on a meta-theoretical level

Several motivational models have been proposed to assist in predicting behaviour. These may be helpful in developing an integrative motivational approach towards employee commitment.

Kanungo (1982a) proposed a model based on a motivational approach where socialisation processes result in salient needs (in work and non-work spheres) which are followed by instrumental behaviours and attitudes. The potential of these behaviours and attitudes to satisfy salient needs (cf. Gorn \& Kanungo, 1980; Kanungo, Misra \& Dayal, 1975; Lefkowitz et al., 1984; Misra \& Kalro, 1981) are then evaluated which result in commitment and alienation and their resulting behaviours. This model has particular limitations as was pointed out by Roodt (1991). One of the limitations is that the conflict potential between different life roles and the resulting struggle for establishing equilibrium between these roles are not fully reflected in this model. The role of defence mechanisms (as an important motivational mechanism) in this aforementioned process is also not mentioned. The inclusion of salient values and salient goals as important motivational constructs are also not addressed in Kanungo's (1982a) model.

Locke and Henne (1986) developed a motivational model based on a meta-theoretical analysis of existing work motivation theories that addresses most of these mentioned concerns. According to this model, which evolves from general to specific, behaviour (action) is triggered by salient needs, followed by salient values (Roodt et al., 1994b) and then by salient goals (Roodt et al., 1994b). All the components are moderated by cognitive processes (including the self concept, defence mechanisms and instrumental perceptions), while goals specifically are also influenced by emotional content. This model is illustrated in Figure 3.

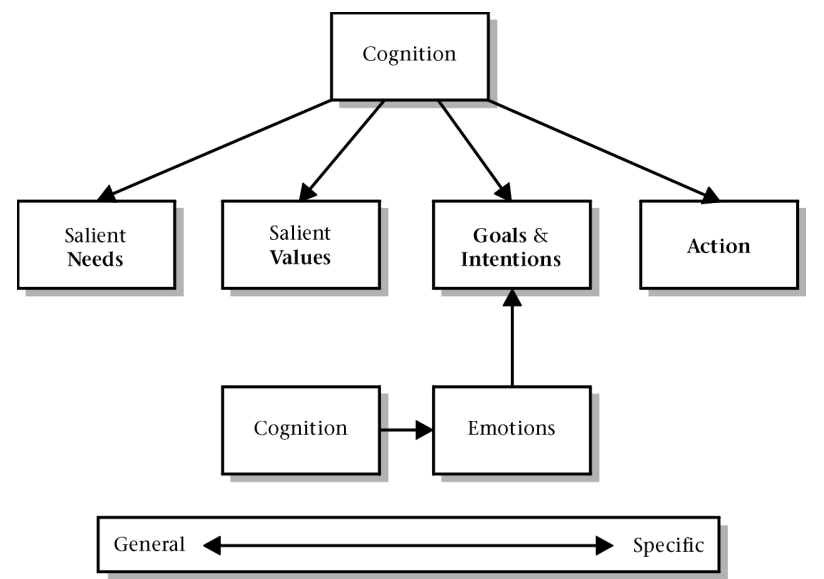

Figure 3: A basic motivational process (adapted from Locke \& Henne, 1986, p. 2)

These two motivational models clearly indicate that specific instrumental actions would lead to salient need satisfaction and if successful, also to a positive emotional state. Positive emotions act as feedback to assess future values and goals for their need satisfaction potential. Instrumental perceptions (Day, 1994) also play a major role in selecting appropriate actions in commitment and alienation conditions (cf. Scholl, 1981 and Wiener, 1982). This motivational process can be illustrated as follows:

This model is suggested as a base-line model for explaining the state of commitment (the alienation - commitment continuum). The model can be applied in different contexts, i.e. work, family and leisure, or can be directed to different foci in the work context. The model suggests that the commitment process remains the same regardless of the context or the focus in question. The proposed model therefore addresses the redundancy problem with regard to different types of engagement (the terminology redundancy problem) and resolves the need for different measures in different commitment foci. It seems as if the motivational approach overcomes most of the mentioned limitations of the two other approaches to commitment.

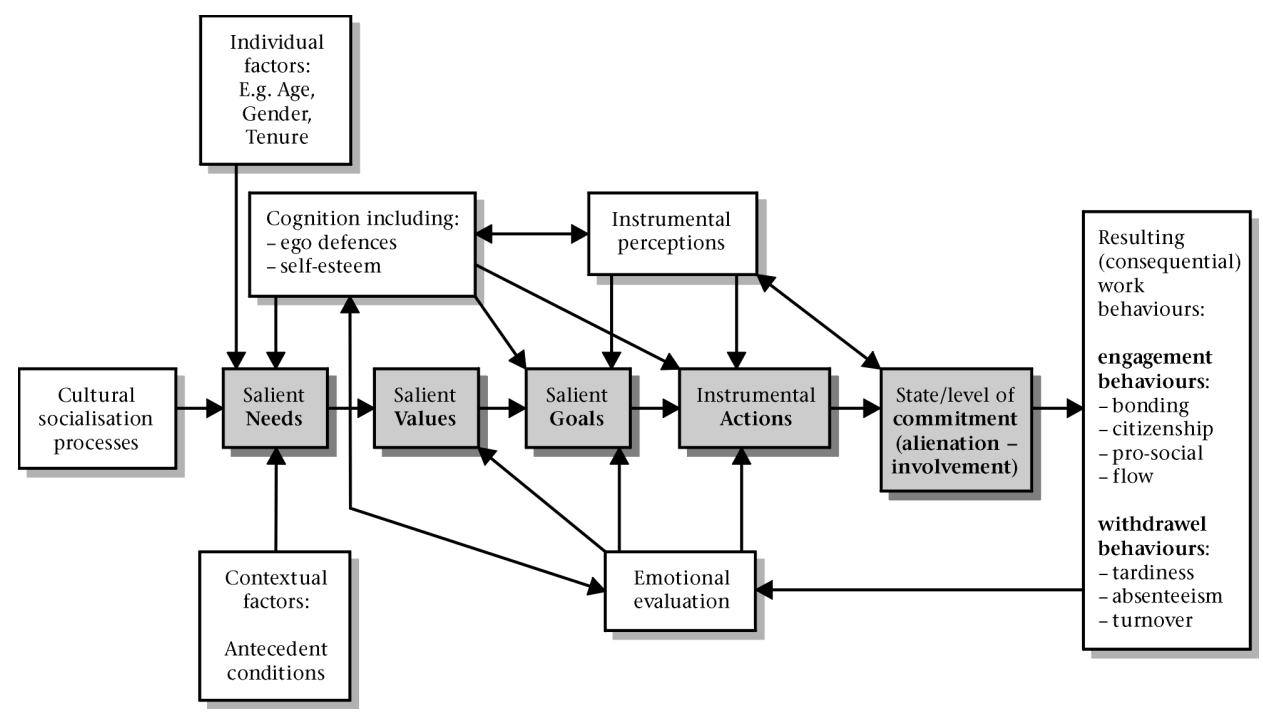

Figure 4: A baseline motivational model for illustrating work commitment - alienation 
The model also clearly distinguishes between the antecedents, the consequences of commitment and the state of commitment itself. It also high-lights the influences of instrumental perceptions (expectancy) and emotions and also distinguishes resulting (consequential) behaviours on the alienation commitment continuum.

Clearly in terms of this continuum, the inability of a particular focus to satisfy salient needs will result in low commitment (alienation). In the case of excessive commitment salient needs will revolve around avoiding irrational fears of boredom or fears of failure. Commitment can therefore be conceptualised as different levels on a continuum, ranging from alienation to extreme commitment (Roodt et al., 1994a; Roodt, 1991), thereby integrating the three streams of research by using a motivational approach.

\section{Conclusions and recommendations}

It is illustrated in this article that research in the wider field of commitment, did not evolve in a logical and coherent manner, nor was it based on a sound theoretical basis. The developments that did occur were rather fragmented or isolated within different research approaches or categories of a particular research stream. Resulting from this fragmentation, a myriad of different measures emerged to assess commitment or alienation within a wide range of different foci.

The mentioned measures were developed with different and sometimes even poor theoretical bases which make comparisons of results extremely complex and difficult. Some measures did not distinguish between the different psychological activities so that commitment was not defined as a purely cognitive predisposition. Other measures did not isolate the state of commitment from its antecedent and consequent conditions or behaviours. Furthermore, different methodologies were applied in the psychological and the sociological approaches toward studying commitment and alienation respectively. As a result little cognisance was given to theoretical developments in other research streams or across approaches in order to create some kind of integration on a meta-theoretical level. The myriad of measures applicable to a wide range of foci resulted in concept contamination and concept redundancy, because of the poor integration on a meta-theoretical level.

A motivational approach is therefore proposed to establish integration on a meta-theoretical level that would provide a sound theoretical foundation for operationalising commitment as a cognitive predisposition to work or to any particular focus. This theoretical basis would address most causes of concept redundancy and contamination within a particular focus and would also clearly distinguish the state of commitment from its antecedent and consequent conditions. Furthermore, it would also isolate the state of commitment as a cognitive predisposition from its related affect (emotions) and conation (intentions). This would most likely result in a precise and pure definition of the commitment construct. Although there is empirical evidence for some of the elements in this model, it needs to be empirically tested as a whole.

The proposed theoretical basis and integration would hopefully result in a more homogeneous approach among researchers in studying commitment across different foci and contexts.

\section{REFERENCE}

Adorno, T.W. (1950). The Authoritarian Personality. New York: Harper Brothers.

Allen, N.J. \& Meyer, J.P. (1990). The measurement and antecedents of affective, continuance and normative commitment to the organisation. Journal of Occupational Psychology, 63, 1-18.
Allen, N.J. \& Meyer, J.P. (1996). Affective, continuance, and normative commitment to the organization: An examination of construct validity. Journal of Vocational Behavior, 49, 252-276.

Allen, S. \& Ortlepp, K. (2002). Conceptualising and operationalising work versus career salience. SA Journal of Industrial Psychology, 28 (2), 7-14.

Allport, G.W. (1943). The ego in contemporary psychology. Psychological Review, 50, 451-476.

Allport, G.W. (1947). The psychology of participation. Psychological Review, 52, 117-132.

Amatea, E.S., Cross, E.G., Clark, J.E., \& Bobby, C.L. (1986). Assessing the work and family role expectations of careerorientated men and women: The Life Role Salience Scales. Journal of Marriage and the Family, 48, 831-838.

Bagraim, J.J. (2003). The dimensionality of professional commitment. SA Journal of Industrial Psychology, 29 (2), 6-9.

Becker, H.S. (1960). Notes on the concept of commitment. American Journal of Sociology, 66, 32-40.

Blau, G.J. (1985). A multiple study investigation of the dimensionality of job involvement. Journal of Vocational Behavior, 27, 19-36.

Blau, G.J. (1988). Further exploring the meaning and measurement of career commitment. Journal of Vocational Behavior, 32, 284-297.

Blood, M. (1969). The measurement and prediction of career commitment. Journal of Occupational Psychology, 58, 277-288.

Bonjean, C.M. \& Grimes, M. D. (1970). Bureaucracy and alienation: a dimensional approach. Social Forces, 48, 365-373.

Brooke, P.P., Russell, D.W. \& Price, J.L. (1988). Discriminant validation of measures of job satisfaction, job involvement, and organizational commitment. Journal of Applied Psychology, 73 (2), 139-145.

Brown, M.E. (1969). Identification of some conditions of organizational involvement. Administrative Science Quarterly, 14, 346-355.

Brown, R.B. (1996). Organizational commitment: Clarifying the concept and simplifying the existing construct typology. Journal of Vocational Behavior, 49, 230-251.

Brown, S.P. (1996). A meta-analysis and review of organizational research on job involvement. Psychological Bulletin, 120 (2), 235-255.

Burke, R.J. \& Deszca, E. (1982). Career success and personal failure experiences and type A behaviour. Journal of Occupational Behaviour, 3, 161-170.

Cheloha, R.S. \& Farr, J.L. (1980). Absenteeism, job involvement, and job satisfaction in an organizational setting. Journal of Applied Psychology, 65 (4), 467-473.

Chonko, L.B. (1983). Job involvement as obsession-compulsion: Some preliminary findings. Psychological Reports, 53, 1191 1197.

Cook, J.D., Hepworth, S.J., Wall, T.D. \& Warr, P.B. (1979). The experience of work. London: Academic Press.

Cook, J.D. \& Wall, T.D. (1980). New work attitudes measures of trust, organisational commitment and personal need nonfulfilment. Journal of Occupational Psychology, 53, 39-52.

Coster, E.A. (1992). The perceived quality of working life and job facet satisfaction. Journal of Industrial Psychology, 18 (2), 6-9.

Cummings, T.G. \& Bigelow, J. (1976). Satisfaction, job involvement, and intrinsic motivation: An extension of Lawler and Hall's factor analysis. Journal of Applied Psychology, 61 (4), 523-525.

Day, N.E. (1994). Organisational commitment and instrumentality perceptions: Differentiating the concepts. Paper presented at the Second Biennial International Conference on Advances in Management. Calgary, Canada, June 17- 20.

Dean, D.G. (1961). Alienation: Its meaning and measurement. American Sociological Review, 26, 753-758.

DeGrazia, S. (1948). The political community: A study of anomie. Chicago: University of Chicago. 
Dubin, R. (1956). Industrial workers' worlds: A study of the "central life interests" of industrial workers. Social Problems, 3, 131-142.

Dubin, R. (1961). Human Relations in Administration. Englewood Cliffs, N.J.: Prentice-Hall.

Durkheim, E. (1893). De la division du travail social. Paris: F. Alcan.

Etzioni, A. (1964). Modern Organizations. Englewood Cliffs, N.J.: Prentice-Hall, Inc.

Fishbein, M. (1967). Readings in attitude theory and measurement. New York: John Wiley \& Sons, Inc.

Fishbein, M. \& Ajzen, I. (1975). Belief, attitude, intention and behavior: An introduction to theory and research. Reading, Mass.: Addison-Wesley Publishing Co.

Fleming, J.H. (2000a). Relating employee engagement and customer loyalty to business outcomes in the financial service area. Gallup Research Journal, 3 (1), 91-101.

Fleming, J.H. (2000b). Relating employee engagement and customer loyalty to business outcomes in the retail industry. Gallup Research Journal, 3 (1), 103-115.

Forrest, C.R., Cummings, L.L. \& Johnson, A.C. (1977). Organizational participation: A critique and model. Academy of Management Review, 2, 586-601.

French, J.R.P. \& Kahn, R.L. (1962). A programmatic approach to studying the industrial environment and mental health. Journal of Social Issues, 18, 1-47.

Fromm, E. (1958). Escape from freedom. New York: Harper and brothers.

Fullagar, C. \& Barling, J. (1989). Longitudinal test of a model of the antecedents and consequences of union loyalty. Journal of Applied Psychology, 74 (2), 213-227.

Gechman, A.S. \& Wiener, Y. (1975). Job involvement and satisfaction as related to mental health and personal time devoted to work. Journal of Applied Psychology, 80 (4), 521523.

Gordon, M.E, Philpot, J.W., Burt, R.E., Thompson, C.A. \& Spiller, W.E. (1980). Commitment to the union: Development of a measure and a examination of its correlates. Journal of Applied Psychology, 65, 479-499.

Gorn, G.J. \& Kanungo, R.N. (1980). Job involvement and motivation: Are intrinsically motivated managers more job involved? Organisational Behavior and Human Performance, 26, 265-277.

Greenhaus, J.H. (1971). An investigation of the role of career salience in vocational behaviour. Journal of Vocational Behavior, 1, 209-216.

Grodzins, M. (1956). The loyal and the disloyal. Chicago: University of Chicago Press.

Guion, R. (1958). Industrial morale - the problem of terminology. Personnel Psychology, 11, 59-61.

Hall, D.T., Schneider, B. \& Nygren, H.T. (1970). Personal factors in organizational identification. Administrative Science Quarterly, 15, 176-190.

Harter, J. (2000a). The linkage of employee perceptions and outcomes in a retail environment: Cause and effect? Gallup Research Journal, 3 (1), 25-38.

Harter, J. (2000b). Managerial talent, employee engagement and business-unit performance. The Psychologist - Manager Journal, 3 (1), 55-61.

Hegel, G.W.F. (1949). Phenomenology of Mind, translated by J.B. Baillie. New York: MacMillan.

Hollon, C.J. \& Chesser, R.J. (1976). The relationship of personal influence dissonance to job tension, satisfaction and involvement. Academy of Management Journal, 19, 308-314.

Hoole, C. (1997). Work commitment: Its dimensions and relationships with role stress and intention to quit. Unpublished D Phil dissertation. Pretoria: University of Pretoria.

Jaco, E. G. (1954). The social isolation hypothesis and schizophrenia. American Sociological Review, 19, 567-577.

Jans, N.A. (1982). The nature and measurement of work involvement. Journal of Occupational Psychology, 55, 57-67.
Kanungo, R.N. (1979). The concepts of alienation and involvement revisited. Psychological Bulletin, 86 (1), 119-138.

Kanungo, R.N. (1981). Work alienation and involvement: Problems and prospects. International Review of Applied Psychology, 30, 1-15.

Kanungo, R.N. (1982a). Work Alienation: An Integrative Approach. New York: Preager

Kanungo, R. N. (1982b). Measurement of job and work involvement. Journal of Applied Psychology, 67 (3), 341-349.

Kanungo, R.N., Misra, S.B. \& Dayal, I. (1975). Relationship of job involvement to perceived importance and satisfaction of employee needs. International Review of Applied Psychology, 24 (1), 49-59.

Keniston, K. (1957). Alienation and the decline of utopia. The American Scholar, 29, 164.

Kerlinger, F.N. (1986). Foundations of Behavioral Research. New York: CBS Publishing.

Knapp, R.J. (1976). Authoritarianism, alienation, and related variables: A correlational and factor-analytic study. Psychological Bulletin, 1976, 83, 194-212.

Knoop, R. (1986). Job involvement: An elusive concept. Psychological Reports. 59, 451-456.

Kris, E. \& Leites, N. (1950). Trends in twentieth century propaganda. In Berelson, B. \& Janowitz, M. (eds.) Reader in Public Opinion and Communication, Glencoe, Illinois: The Free Press.

Lawler, E.E. \& Hall, D.T. (1970). Relationship of job characteristics to job involvement, satisfaction and intrinsic motivation. Journal of Applied Psychology, 54 (4), 305-312.

Lefkowitz, J. \& Brigando, L. (1980). The redundancy of work alienation and job satisfaction: Some evidence of convergent and discriminant validity. Journal of Vocational Behavior, 16, $115-131$

Lefkowitz, J., Somers, M.J. \& Weinberg, K. (1984). The role of need level and/or need salience as moderators of the relationship between need satisfaction and work alienation involvement. Journal of Vocational Behavior, 24, 142-158.

Lodahl, T.M. \& Kejner, M. (1965). The definition and measurement of job involvement. Journal of Applied Psychology, 49 (1), 24-33.

Locke, E.A. \& Henne, D. (1986). Work motivation theories. In Cooper, C.L. \& Robertson, I. (eds.) International Review of Industrial and Organisational Psychology. New York: John Wiley \& Sons.

Marx, K. (1963). Early Writings. Edited and translated by T.B. Bottomore. New York: MGraw-Hill.

Mathieu, J.E. \& Farr, J.L. (1991). Further evidence for the discriminant validity of measures of organizational commitment, job involvement and job satisfaction. Journal of Applied Psychology, 76 (1), 127-133.

McDill, E.L. (1961). Anomie, authoritarianism, prejudice and socio-economic status: An attempt at clarification. Social Forces, 39, 239-245.

Merton, M. (1947). Mass Persuasion. New York: Harper and brothers.

Mester, C., Visser, D., Roodt, G. \& Kellerman, R. (2003). Leadership style and its relation to employee attitudes and behaviour. SA Journal of Industrial Psychology, 29 (2), 72-82.

Meyer, J.P., Allen, N.J. \& Smith, C.A. (1993). Commitment to organizations and occupations: extension and test of a threecomponent conceptualization. Journal of Applied Psychology, 78 (4), 538-551.

Misra, S. \& Kalro, A. (1981). Job involvement of intrinsically and extrinsically motivated Indian managers: To each according to his need. Human Relations, 34 (5), 419-426.

Misra, S., Kanungo, R.N., von Rosenstiel, L. \& Stuhler, E.A. (1985). The motivational formulation of job and work involvement: A cross-national study. Human Relations, 38 (6), 501-518.

Morrow, P.C. (1983). Concept redundancy in organizational research: The case of work commitment. Academy of Management Review, 8 (3), 486-500.

Morrow, P.C., Eastman, K. \& McElroy, J.C. (1991). Concept redundancy and rater naivety in organisational research. Journal of Applied Social Psychology, 21 (3), 219-232. 
Morrow, P.C. \& McElroy, J.C. (1986). Research notes on assessing measures of work commitment. Journal of Occupational Behaviour, 7, 139-145.

Morrow, P.C. \& Goetz, J.F. (1988). Professionalism as a form of work commitment. Journal of Vocational Behavior, 32, 92-111.

Mortimer, J.T. \& Lorence, J. (1989). Satisfaction and involvement: Disentangling a deceptively simple relationship. Social Psychology Quarterly, 52 (4), 249-265.

Mowday, R.T., Steers, R.M. \& Porter, L.W. (1979). The measurement of Organizational Commitment, Journal of Vocational Behavior, 37, 224-247.

Naughton, T.J. (1987). A conceptual view of workaholism and implications for career counselling and research. The Career Development Quarterly, 180-187.

Neal, A.G. \& Rettig, S. (1967). On the multidimensionality of alienation. American Sociological Review, 32, 54-64.

Netller, G. (1957). A measure of alienation. American Sociological Review, 22, 670-677.

Newton, T.G. \& Keenan, A. (1983). Is work involvement an attribute of the person or the environment? Journal of Occupational Behaviour, 4, 169-178.

O'Reilly, C. \& Chatman, J. (1986). Organizational commitment and psychological attachment: The effects of compliance, identification and internalization of prosocial behavior. Journal of Applied Psychology, 71 (3), 492-499.

Pace, L.A. \& Suojanen, W.W. (1988). Addictive type A behaviour undermines employee involvement. Personnel Journal, 67 (6), $36,40-42$

Pace, L.A., Suojanen, W.W., Bessinger, R.C., Lee, H., Frederick, R.P. \& Miller, R.E. (1986). The type A manager as addict. Employee Assistance Quarterly, 2 (2), 47-63.

Patchen, M. (1965). Some questionnaire measures of employee motivation and morale. Monograph No 41. Ann Arbor: Institute for Social Research.

Patchen, M. (1970). Participation, achievement and involvement on the job. New Jersey: Prentice Hall Inc.

Pietropinto, A. (1986). The workaholic spouse. Medical aspects of Human Sexuality, 20 (5), 89-96.

Pinder, C.C. (1984). Work motivation: Theory, issues, and applications. Glenview, Ill: Scott, Foresman.

Pollak, J.M. (1979). Obsessive-compulsive personality: A review. Psychological Bulletin, 86 (2), 225-241.

Porter, L.W., Steers, R.M., Mowday, R.T. \& Boulian, P.V. (1974). Organizational commitment, job satisfaction and turnover among psychiatric technicians. Journal of Applied Psychology, $59(5), 603-609$.

Powell, E.H. (1958). Occupation, status and suicide: Toward a redefinition of anomie. American Sociological Review, 23, 131139.

Price, M. (1980). Workaholism: Fears a job can't solve. Industry Week. March 3, pp. 5, 56-59, 62 .

Rabinowitz, S. \& Hall, D.T. (1977). Organizational research on job involvement. Psychological Bulletin, 84 (2), 265-288.

Rabinowitz, S. \& Hall, D.T. (1981). Changing correlates of job involvement in three career stages. Journal of Vocational Behavior, 18, 138-144

Randall, D.M. (1987). Commitment and the organisation: The organization man revisited. Academy of Management Review, $12,460-471$

Reichers, A.E. (1985). A review and reconceptualization of organisational commitment. Academy of Management Review, 10 (3), 465-476.

Reitz, H.J. \& Jewell, L.N. (1979). Sex, locus of control and job involvement: A six country investigation. Academy of Management Journal, 22 (1), 72-80.

Riesman, D. \& Glazer, N. (1950). Criteria for political apathy. In Gouldner, A.W. (ed.), Studies in Leadership. New York: Harper and brothers.

Rokeach, M. \& Bartley, S.H. (1978). Some pitfalls in psychological theorizing. In Jackson, D.N. \& Messick, S. (eds.) Problems in Human Assessment. New York: Robert E. Krieger Publishing Company.
Roodt, G. (1991). Die graad van werkbetrokkenheid as voorspeller van persoonlike welsyn: 'n Studie by bestuurders. [The degree of work commitment as predictor of personal well-being: A study on managers]. Unpublished doctoral dissertation. Bloemfontein: University of the Orange Free State.

Roodt, G. (1993). 'n Ondersoek na die verbondenheid/ betrokkenheidfoki by OVS-Onderwysers [An investigation into the involvement/commitment foci of OFS teachers] Published technical report. Bloemfontein: University of the Orange Free State.

Roodt, G. (1997). Theorectical and empirical linkages between work-related commitment foci. Journal of Industrial Psychology, 23 (2), 6-13.

Roodt, G., Bester, C.L. \& Boshoff, A.B. (1994a). Die graad van werkbetrokkenheid: 'n Bipolêre continuum? [The degree of work commitment: A bipolar continuum?]. Journal of Industrial Psychology, 20 (1), 12-16.

Roodt, G., Bester, C.L. \& Boshoff, A.B. (1994b). Predicting work involvement of managers: Life values and goals. Acta Academica, 26 ( $2 \& 3)$, 154-169.

Rosenberg, M. (1951). The meaning of politics in mass society Public Opinion Quarterly, 15, 5-15.

Ruh, R.A., White, J.K. \& Wood, R.R. (1975). Job involvement, values, personal background, participation in decision making, and job attitudes. Academy of Management Journal 18 (2), 300-312.

Saal. F. E. (1978). Job involvement: A multivariate approach Journal of Applied Psychology, 63 (1), 53-61.

Saal, F.E. (1981). Empirical and theoretical implications of a purely cognitive definition of job involvement. International Review of Applied Psychology, 30, 103-120.

Saleh, S.D. \& Hosek, J. (1976). Job involvement: Concepts and measurements. Academy of Management Journal, 19, 213-224.

Scholl, R.W. (1981). Differentiating Organisational Commitment from expectancy as a motivating force. Academy of Management Review, 6 (4), 589-599.

Schwartz, H.S. (1982). Job-involvement as obsession-compulsion. Academy of Management Review, 7 (3), 429-432.

Seeman, M. (1959). On the meaning of alienation. American Sociological Review, 24, 783-791.

Seybolt, J.W. \& Gruenfeld, L. (1976). The discriminant validity of work alienation and work satisfaction measures. Journal of Occupational Psychology, 49, 193-202.

Simmons, J. L. (1966). Some intercorrelations among 'alienation' measures. Social Forces, 44, 370-372.

Shore, T.H., Thornton, G.C. \& Shore, L.M. (1990) Distinctiveness of three work attitudes: Job Involvement, Organisational Commitment and Career Salience. Psychological Reports, 57, 851-858.

Stagner, R. (1958). Motivational aspects of industrial morale. Personnel Psychology, 11, 64-69

Stewart, J.D. (1986). The Power of People Skills. New York: John Wiley \& Sons, Inc.

Struening, E.L \& Richardson, A.H. (1965). A factor analytic exploration of the alienation, anomia and authoritarianism domain. American Sociological Review, 30, 768-776.

Vroom, V.H. (1962). Ego-involvement, job satisfaction, and job performance. Personnel Psychology, 15, 159-177.

Vroom, V.H. (1964). Work and Motivation. New York: Wiley.

Weissenberg, P. \& Gruenfeld, L.W. (1968). Relationship between job satisfaction and job involvement. Journal of Applied Psychology, 52 (6), 469-473.

Wickert, F.R. (1951). Turnover, and employees' feelings of egoinvolvement in the day-to-day operations of a company. Personnel Psychology, 4, 185-197.

Wiener, Y. (1982). Commitment in organisations: A normative view. Academy of Management Review, 7 (3), 418-428.

Wiener, Y. \& Gechman, A.S. (1977). Commitment: A behavioral approach to job involvement. Journal of Vocational Behavior $10,47-52$. 